\title{
The Analysis of Corporative Reporting Designed to Enhance Corporate Governance: Evidence from the Banking Sector in Croatia
}

\author{
Ivana Đunđek Kokotec * \\ Marina Klačmer Čalopa* \\ Kristina Detelj *
}

\begin{abstract}
The main objective of this research paper is to examine whether the practice of corporate governance $(\mathrm{CG})$ measured by the CGI-Crobank $®$ index is significant for the explanation of variations in the performance of Croatian banks measured by the return on assets, return on equity, interest margin, margin of non-interest income, operating expenses margin, and by Tobin's Q for the observed period from 2011 to 2015. The research is made on Croatian banks that form the CGI-Crobank ${ }^{\circledR}$ index using the data and information from annual questionnaires of CG codex, primarily to ensure objectivity, standardization and comparability. The goal of the literature analysis was to show present findings in the areas of corporate reporting and its impact on CG. Results obtained in the research indicate that a well implemented practice of corporate governance measured by the CGI-Crobank ${ }^{\circledR}$ index have influence on the variations in the performance of Croatian banks measured by Tobin's $\mathrm{Q}$ and financial indicators.
\end{abstract}

Keywords: Corporate governance, bank sector, financial indicator, Tobin’s Q, CGI-Crobank® index JEL Classification: G18, G21, G30, G32, G34

\section{Introduction}

"Effective corporate governance is critical to the proper functioning of the banking sector and the economy as a whole" (Basel Committee on Banking Supervision, 2015). The main proof of good corporate governance in the banking sector is the strengthening of investors' trust and confidence in the economy. For a good financial

\footnotetext{
* Ivana Đunđek Kokotec, Marina Klačmer Čalopa and Kristina Detelj are at Faculty of Organization and Informatics Varaždin, University of Zagreb, Varaždin, Croatia.
} 
performance, it is crucial that the banking sector perceives and adopts a strong corporate governance ethos (Adegbemi, Donald, Ismail, 2012).

\section{Literature Review}

There have been several studies performed in the Republic of Croatia related to the profitability and success of the Croatian banking sector Kraft, Tirtiroglu, 1998; Pejic Bach, Posedel, Stojanovic, 2009; Tomicic, Coric, Klacmer Calopa, 2012).

Pervan, Pelivan and Arneric (2015) conclude that the statistically significant variables with a positive influence on bank's profitability are the following: profitability from the previous year, bank size, solvency risk, intermediation, industry concentration, market growth and GDP growth; while variables of credit risk, inflation and operating expenses management have negative and statistically significant impact on profitability. Previous research indicated that the correlation between corporate governance and bank performance is still not clearly established and the research results are quite diverse. Firstly, it is due to the fact that there are no defined measuring metrics/tools for corporate governance in the banking sector. Many research papers investigate the correlation between ownership structure and bank performance. An empirical analysis on 32 Croatian banks was performed with the purpose to examine the structure of bank ownership and its impact on the selected performance indicators. Tomicic, Coric and Klacmer Calopa (2012) found that measures of performance (return on assets, return on equity) tend to show statistically significant correlation with bank's ownership structure. The research performed on the 25 listed banks in Bangladesh over the period 2003-2011 shows that corporate governance mechanisms have a positive and significant influence on return on assets, return on equity and Tobin's Q (Mohammad, Rabiul, Hasnan, 2013). In another research on the sample of 17 listed banks in Pakistan, Imran et al. (2014) found that corporate governance shows significant positive impact on the financial efficiency measured with return on assets and return on equity. Using a sample of 107 banks in Russia and 50 banks in Ukraine, Love and Rachinsky (2015) found significant but economically unimportant relationship between corporate governance and bank performance. The study of Saudi Arabian banks (Al-Sahafi, Rodrigs, Barnes, 2015) found that board size, board independence and bank size have a significant positive impact on banks' financial performance, whereas ownership concentration and leverage ratio have a significant negative impact on banks' financial performance measured by return on assets, return on equity and Tobin's Q. Using a Corporate Governance Index (CGI) as a scoring model which analyses four macro areas of governance (board, compensation, shareholder and stakeholder rights and disclosure) Bubbico, Giorgino and Monda (2012) also found a positive and statistically significant relationship between corporate governance and bank performance. 


\section{Research Goals and Hypothesis}

The objective of this research is to examine whether the practice of corporate governance measured by the CGI-Crobank ${ }^{\circledR}$ index is significant for the explanation of variations in the performance success, i.e. the profitability of banks measured by the return on assets, return on equity, interest margin, margin of non-interest income, operating expenses margin, and by Tobin's Q for the observed period of 5 years, from 2011 to 2015. Based on the defined problems and research objectives in this paper, a scientific-research task was determined consisting of testing the following hypotheses:

$\mathbf{H}_{1}$ : Corporate governance practice measured by CGI-Crobank ${ }^{\circledR}$ index is significant in the explanation of the variations in the performance success measured by the return on assets for the observed period from 2011 to 2015.

$\mathbf{H}_{2}$ : Corporate governance practice measured by CGI-Crobank ${ }^{\circledR}$ index is significant in the explanation of the variations in the performance success measured by the return on equity for the observed period from 2011 to 2015 .

$\mathbf{H}_{3}$ : Corporate governance practice measured by CGI-Crobank ${ }^{\circledR}$ index is significant in the explanation of the variations in the performance success measured by the interest margin, for the observed period from 2011 to 2015 .

$\mathbf{H}_{4}$ : Corporate governance practice measured by CGI-Crobank ${ }^{\circledR}$ index is significant in the explanation of the variations in the performance success measured by the margin of non-interest income for the observed period from 2011 to 2015.

$\mathbf{H}_{5}$ : Corporate governance practice measured by CGI-Crobank ${ }^{\circledR}$ index is significant in the explanation of the variations in the performance success measured by the operating expenses margin for the observed period from 2011 to 2015.

H. $_{\text {: }}$ Corporate governance practice measured by CGI-Crobank $®$ index is significant in the explanation of the variations in the performance success measured by Tobin's Q for the observed period from 2011 to 2015.

The simple linear regression model analytically expresses the relation between the two phenomena presented by the numerical variable values. This research used the semi-log linear model which reduced the non-linear model to a linear model by logarithmic transformation of the dependent variable. Thus, the developed CGI-Crobank ${ }^{\circledR}$ index represents the independent variable, while the performance (profitability) indicators of the banks represent the dependent variables. $\beta_{0}$ and $\beta_{1}$ represent the unknown regression coefficients, and $\varepsilon$ is a variable of the non-systematic influence on the dependent variable making this model a stochastic one.

$$
\log _{1}=\beta_{0}+\beta_{1} x+\varepsilon_{1}
$$

Least Squares method (LS method) was used for assessing the parameters, having met the starting premises in the analysis of the simple linear regression model (Bahovec, Erjavec, 2009). 


\section{Research Methodology}

The conducted research includes the analysis of the annual questionnaires of the codex of corporate governance in the banks listed on the Zagreb Stock Exchange (ZSE) in the period between 2011 and 2015. In this period only nine ( $n=9)$ banks had available annual questionnaires of the codex of corporate governance for each of the analysed years. The intentional sample, chosen by the evaluation of the researchers, comprises Hrvatska postanska banaka d.d.; Istarska kreditna banka Umag d.d.; Karlovacka banka d.d.; Kreditna banka Zagreb d.d.; Podravska banka d.d.; Privredna banka Zagreb d.d.; Slatinska banka d.d.; Vaba banka d.d.; Zagrebac$k a$ banka d.d. The real samples in the analysis correspond to the targeted samples because we observed only banks which had the annual questionnaires of the codex of corporate governance available for each of the analysed years which we used to measure the practice of corporate governance and the developed CGI-Crobank ${ }^{\circledR}$ index. Also, there were cases of unanswered questions in certain banks, which might arise from the fact that the Codex as such is optional. Similarly, this might indicate to unserious and unprofessional approach of the bank management to this problem area. The availability of the annual corporate governance questionnaires indicates to management the corporate governance practice, especially from the transparency point of view.

\section{Independent Variable}

Within the framework of researching the existence of dependability of successful performance on the corporate governance practice, the authors Korent, Dundek and Klacmer Calopa (2014) formed the Croatian Corporate Governance Index (CCGI®). The methodology of alternative measuring of corporate governance quality represents the basis for implementation of this research. Corporate Governance Index (CGI-Crobank $\left.{ }^{\circledR}\right)$ was taken as an independent variable in this research and it represents a measure based on the corporate governance practice of the banks in the sample. The index was developed by analysing the answers to the questions from annual questionnaires, total of 64, which are characterized by dichotomy. Accordingly, the affirmative answer was coded with value 1 , negative with value 0 , while the questions which remained unanswered by the banks were taken into consideration as an average value calculated based on given answers to the remaining analysed questions. All the questions included in the analysis were formulated in a way that a desirable answer was affirmative. Namely, the 64 analysed elements in the annual questionnaire were grouped in five subindexes (Subindexes I - V), and the division on subindexes corresponds to the chapters of the Codex of Corporate Governance which regulate the areas of public advertising, work of the Assembly, 
Supervisory Board and Board of Management, auditing and internal control mechanisms, relations to investors and interest holders, as well as publishing data on the adherence to the provisions of the Codex. The subindexes were calculated by summing up all the answers to the questions within a certain subindex. The gained sum was divided by the maximum achieved sum of the subindex in a particular year, which ensured for the subindex to get a value in the interval zero to one. Other subindexes were calculated analogously. Each subindex was awarded equal weight. Finally, the bank corporate governance index was calculated by summing up the values of all the five subindexes. The gained sum was then divided by the total number of subindexes.

\section{Dependent Variables}

The information on the bank performance success based on the financial reports is needed for the public, being the user of bank services, as well as for a potential investor into stock capital, regulators from the aspect of controlling the stability of the financial system, and for financial analysts, owners, management and the professional and scientific public. Furthermore, the performance profitability is a result of successful implementation of bank's business policy measures. In order to quantify the results of the successful, i.e. unsuccessful bank business performance, the indicators of bank profitability are being used (Pavkovic, 2004). The profitability indicators measure the return on the invested capital, which is considered to be the highest level of governance efficiency. Based on that, the profitability indicators were taken as dependent variables in this research. The profitability indicators include the return on assets, return on equity, interest margin, margin of non-interest income, operating expenses margin and Tobin $\mathrm{Q}$. The return on assets indicates the extent to which the net profit is created as a percentage of total average bank assets, i.e. the bank profit per kuna assets in lipa terms; if the ratio is higher than 1, the investment in stock of that bank is considered as profitable (Pavkovic, 2004). Just as the rate of return on assets, so does the rate of return on equity represent an accounting rate. Further on, the rate measures the return on equity, i.e. it shows the bank's accounting profit per kuna of bookkeeping capital in lipa terms (Zager, Mamic Sacer, Sever, Zager, 2009). The interest margin, i.e. the net interest margin, indicates the interest revenues as a percentage of the bank's average assets. It should be noted that the interest margin depends on the level of development of the financial system of a certain country, size of the bank and its position in relation to the competition, as well as the bank's business environment, size of assets and so on. The indicators of non-interest margin income and operational expenses margin are very significant within the context of margin indicators. Further on, it is emphasized that a well-organized bank does business in a way that the interest margin covers the margin of operational cost, while the non-in- 
terest income margin sustains its result (Zager, Mamic Sacer, Sever, Zager, 2009). The mentioned indicators are based on the accounting, and their biggest disadvantage is the lack of reflection of real value for the shareholders. Based on this, alternative methods for evaluation of business performance arise as the criticism of the traditional ratios and a way of removing the disadvantages of their implementation. For this reason, along with the above mentioned indicators, Tobin's Q was introduced in the research as a dependent variable and a modern measure of business performance (Pavkovic, 2004). Tobin's Q measures the business performance success at a level of creating value. Namely, Tobin's $Q$ represents the relation of market and bookkeeping value that can be indirectly influenced by well conducted corporate governance, and for this reason it is considered to be an important indicator. In its original form, Tobin's Q represents the ratio of the sum of market debt value and company stocks divided by assets replacement expenses (Klapper, Love, 2002). In this research approximation of the original form was used, and the indicator was calculated by putting into relation the market value of a particular bank's shares and bookkeeping value of the equity capital. It should be noted that the share market value represents the sum gained as product of multiplication of the number of ordinary shares and the last market price of those shares on the last day of trading in a specific observed year, and of the number of privileged shares and the last market price of those shares on the last day of trading in a specific year observed.

\section{Descriptive Analysis of Data}

Table 1 present summary statistics for the six (6) key variables use in this study for the period of five years from 2011 to 2015. There is a wide variation in corporate governance and financial performance measures across the analysed banks. The average value of Corporate Governance Index (CGI-Crobank $®$ ) used as the alternative measuring of corporate governance is around 0,87 in observed period from 2011 to 2015. Analysed indicator increase over the observed period which indicates an increase in the quality of corporate governance overall. If we are analysing the financial performance measurement across analysed banks it can be seen that all indicators point to the relative stability with the exception of net interest margin, return on asset and Tobin Q. Relatively large changes in the movement above mention indicators are result of global financial crisis in the period from 2008 to 2015 which had a big impact on the financial stability and process of loan conversion that caused huge losses and in the and has direct impact on profitability measurement in each analysed bank. 
The Analysis of Corporative Reporting Designed to Enhance Corporate Governance: Evidence from the ...

Table 1: Summary statistics

\begin{tabular}{|c|c|c|c|c|c|c|}
\hline $\mathrm{N}=9$ & Year & Mean & Median & Maximum & Minimum & Std. Dev. \\
\hline \multirow{5}{*}{ CGII } & 2011 & 0.8907 & 0.9103 & 0.9666 & 0.8141 & 0.0516 \\
\hline & 2012 & 0.8744 & 0.8647 & 0.9903 & 0.8264 & 0.0511 \\
\hline & 2013 & 0.8988 & 0.8930 & 0.9600 & 0.8372 & 0.0446 \\
\hline & 2014 & 0.8947 & 0.8841 & 0.9600 & 0.8245 & 0.0461 \\
\hline & 2015 & 0.8358 & 0.8219 & 0.8952 & 0.7476 & 0.0469 \\
\hline \multirow{5}{*}{$\operatorname{lnMKP}$} & 2011 & -0.1439 & -0.1197 & 0.0403 & -0.4423 & 0.1388 \\
\hline & 2012 & -0.1636 & -0.1309 & -0.0006 & -0.4264 & 0.1268 \\
\hline & 2013 & -0.1729 & -0.1148 & -0.0133 & -0.4216 & 0.1376 \\
\hline & 2014 & -0.1541 & -0.1036 & -0.0017 & -0.3983 & 0.1347 \\
\hline & 2015 & -0.1561 & -0.1080 & 0.0116 & -0.0355 & 0.1693 \\
\hline \multirow{5}{*}{ lnMOT } & 2011 & 0.1458 & 0.4274 & 0.6558 & -2.4174 & 0.9714 \\
\hline & 2012 & 0.4576 & 0.4865 & 0.6095 & 0.2017 & 0.1442 \\
\hline & 2013 & 0.4611 & 0.4548 & 0.8412 & 0.1929 & 0.1946 \\
\hline & 2014 & 0.4697 & 0.4574 & 0.9032 & 0.2156 & 0.2074 \\
\hline & 2015 & 0.4031 & 0.3754 & 0.5682 & 0.2421 & 0.1031 \\
\hline \multirow{5}{*}{$\operatorname{lnNKM}$} & 2011 & 0.4748 & 0.4542 & 0.5931 & 0.3572 & 0.0772 \\
\hline & 2012 & 0.4014 & 0.4099 & 0.5098 & 0.1783 & 0.0951 \\
\hline & 2013 & 0.3675 & 0.3969 & 0.5144 & 0.1711 & 0.1000 \\
\hline & 2014 & 0.3522 & 0.378 & 0.4890 & 0.0412 & 0.1418 \\
\hline & 2015 & 0.3551 & 0.3918 & 0.5008 & 0.2145 & 0.1073 \\
\hline \multirow{5}{*}{$\operatorname{lnSPDK}$} & 2011 & 0.5667 & 0.6298 & 1.0063 & 0.0000 & 0.3916 \\
\hline & 2012 & 0.5263 & 0.7307 & 0.8582 & 0.0000 & 0.3510 \\
\hline & 2013 & 0.4367 & 0.4608 & 2.2683 & -0.6418 & 0.8194 \\
\hline & 2014 & 0.2464 & 0.0000 & 0.8518 & -0.6512 & 0.4960 \\
\hline & 2015 & 0.2378 & 0.0000 & 0.8396 & -0.0761 & 0.3417 \\
\hline \multirow{5}{*}{$\operatorname{lnSRI}$} & 2011 & -0.1557 & -0.1324 & 0.2661 & -0.6021 & 0.2643 \\
\hline & 2012 & -0.1952 & -0.1901 & 0.0922 & -0.5754 & 0.2243 \\
\hline & 2013 & -0.5590 & -0.3596 & 0.0000 & -1.5805 & 0.5616 \\
\hline & 2014 & -0.2698 & 0.0000 & 0.0562 & -1.5703 & 0.5259 \\
\hline & 2015 & -0.3011 & -0.1578 & 0.0000 & -0.9839 & 0.3576 \\
\hline \multirow{5}{*}{$\operatorname{lnTQ}$} & 2011 & -0.0530 & -0.0767 & 0.1192 & -0.2759 & 0.1360 \\
\hline & 2012 & -0.1964 & -0.1699 & -0.0317 & -0.4231 & 0.1266 \\
\hline & 2013 & -0.1986 & -0.1417 & 0.0453 & -0.6349 & 0.2246 \\
\hline & 2014 & -0.3367 & -0.2765 & -0.0466 & -1.0203 & 0.3112 \\
\hline & 2015 & -0.2985 & -0.1611 & 0.0000 & -0.9402 & 0.2902 \\
\hline
\end{tabular}

Sources: Author's calculations, an extract from software package EViews 


\section{Research Results}

The objective of the research was to generate models of simple linear regression of dependability of individual indicators of bank profitability and the modern indicator of business performance success, Tobin's $Q$, for the observed period on the corporate governance practice. For all the models starting linear regression premises were met. Based on the defined research objective, six hypotheses were set and tested by the method of simple linear regression, and the empirical results (Table 2) were obtained by the analysis of the gathered data in EViews software package.

Table 2: Models of simple linear regression

\begin{tabular}{|c|c|c|c|c|c|c|}
\hline \multicolumn{2}{|l|}{$\log \hat{y}=\beta 0+\beta 1 * C G I I$} & \multirow{2}{*}{$\begin{array}{r}2011 \\
-0.08 \\
\end{array}$} & \multirow{2}{*}{$\begin{array}{c}2012 \\
1.32 \\
\end{array}$} & \multirow{2}{*}{$\begin{array}{c}\mathbf{2 0 1 3} \\
5.50 \\
\end{array}$} & \multirow{2}{*}{$\begin{array}{c}2014 \\
8.29 \\
\end{array}$} & \multirow{2}{*}{$\begin{array}{r}2015 \\
-2.73 \\
\end{array}$} \\
\hline \multirow{4}{*}{$\begin{array}{l}\text { Return on assets } \\
=\beta 0+\beta 1 * \text { CGII }\end{array}$} & Coefficient & & & & & \\
\hline & $\mathrm{p}$ value & 0.48 & 0.21 & $0.11 * * * *$ & $0.01 * *$ & 0.17 \\
\hline & R-squared & 0.00 & 0.09 & 0.19 & 0.53 & 0.12 \\
\hline & $\mathrm{r}$ & 0.00 & 0.30 & 0.43 & 0.73 & 0.35 \\
\hline \multirow{4}{*}{$\begin{array}{l}\text { Return of equity } \\
=\beta 0+\beta 1 * \text { CGII }\end{array}$} & Coefficient & 6.38 & 4.10 & 2.62 & 6.08 & -0.08 \\
\hline & $\mathrm{p}$ value & $0.00 *$ & $0.04 * *$ & 0.35 & $0.05 * * *$ & 0.48 \\
\hline & R-squared & 0.70 & 0.35 & 0.02 & 0.32 & 0.00 \\
\hline & $\mathrm{r}$ & 0.84 & 0.59 & 0.14 & 0.56 & 0.00 \\
\hline \multirow{4}{*}{$\begin{array}{l}\text { Net Interest Margin } \\
=B 0+\beta 1 * \text { CGII }\end{array}$} & Coefficient & -0.31 & 0.63 & 0.85 & 1.08 & 1.42 \\
\hline & $\mathrm{p}$ value & 0.29 & 0.18 & 0.15 & 0.17 & $0.03 * *$ \\
\hline & R-squared & 0.04 & 0.11 & 0.14 & 0.12 & 0.39 \\
\hline & $\mathrm{r}$ & 0.20 & 0.33 & 0.37 & 0.35 & 0.62 \\
\hline \multirow{4}{*}{$\begin{array}{l}\text { Margin of non-interest income } \\
=\beta 0+\beta 1 * \text { CGII }\end{array}$} & Coefficient & 0.97 & 0.87 & 1.46 & 1.45 & 1.67 \\
\hline & $\mathrm{p}$ value & 0.16 & 0.17 & $0.09 * * *$ & $0.08 * * *$ & 0.10 **** \\
\hline & R-squared & 0.13 & 0.12 & 0.22 & 0.24 & 0.21 \\
\hline & $\mathrm{r}$ & 0.36 & 0.35 & 0.47 & 0.49 & 0.46 \\
\hline \multirow{4}{*}{$\begin{array}{l}\text { Operating expenses margin } \\
=\beta 0+\beta 1 * \text { CGII }\end{array}$} & Coefficient & -7.07 & -2.46 & -2.46 & -0.61 & -0.27 \\
\hline & $\mathrm{p}$ value & 0.15 & $0.00 *$ & $0.05^{* * * *}$ & 0.36 & 0.37 \\
\hline & R-squared & 0.14 & 0.76 & 0.31 & 0.01 & 0.01 \\
\hline & $\mathrm{r}$ & 0.37 & 0.87 & 0.56 & 0.10 & 0.10 \\
\hline \multirow{4}{*}{$\begin{array}{l}\text { Tobin Q }(\log \mathrm{TQ}) \\
=ß 0+\beta 1 * \text { CGII }\end{array}$} & Coefficient & 1.29 & 1.30 & 1.50 & 5.17 & 3.21 \\
\hline & $\mathrm{p}$ value & $0.09 * * *$ & $0.07 * * *$ & 0.21 & $0.00 *$ & $0.07 * * *$ \\
\hline & R-squared & 0.24 & 0.27 & 0.08 & 0.58 & 0.27 \\
\hline & $\mathrm{r}$ & 0.49 & 0.52 & 0.28 & 0.76 & 0.52 \\
\hline \multicolumn{2}{|l|}{$\mathrm{N}$} & 9 & 9 & 9 & 9 & 9 \\
\hline
\end{tabular}

notes: $* \mathbf{p}<0.01 ; * * \mathbf{p}<0.05 ; * * * \mathbf{p}<0.10 ; * * * * \mathbf{P}<0.12$

Sources: Author's calculations, an extract from software package EViews 
Based on the obtained results from the conducted analysis, it can be concluded that that the corporate governance practice measured by CGI-Crobank® index is significant for explaining of variations in the business performance measured by the return on assets in 2013 and $2014\left(\mathrm{H}_{1}\right)$, with the level of significance of $12 \%$ in 2013 and $5 \%$ in 2014, the null hypothesis $\mathrm{H}_{0}$ is rejected. In this way, the change in the quality of corporate governance by 1 will result in an increase of return on asset by the average of 5,50 percent (2013), respectively 8,29 percent (2014). This also indicates the existence of positive linear link among the observed variables. The determination coefficient of the observed model amounts to 0,1910 (2013), that is 0,5304 (2014), which is considered acceptable. The correlation coefficient $(r=0.43)$ indicated to medium level of positive linear connection of the variables in the model.

If we observe the influence of corporate governance on variation in the success of business performance measured by the net interest margin, with the level of significance of $5 \%$, the null hypothesis $\mathrm{H}_{0}$ is rejected. The conclusion is that the corporate governance measured by CGI-Crobank ${ }^{\circledR}$ index is significant for the explanation of variations in the successful performance measured by the net interest margin $\left(\mathrm{H}_{3}\right)$. Further on, the semi-log linear model shows that if the quality of corporate governance in the analysed banks increases by 1 within the CGI-Crobank $®$ index context, the success of business performance measured by the net interest margin will increase in average by 1,42 percent. Among the observed variables there is a positive linear link of medium intensity $(r=0.682$, and the model itself interprets $39,05 \%$ of deviations.

With the significance level of $1 \%$ in 2012 and 10\% in 2013 the null hypothesis $\mathrm{H}_{0}$ for mention year is rejected. In other words, it can be concluded that the corporate governance practice measured by the CGI-Crobank ${ }^{\circledR}$ index is significant for the explanation of variations in the business performance success measured by the operating expenses margin in 2012 and $2013\left(\mathrm{H}_{5}\right)$. Accordingly, if the quality of corporate governance, measured by the CGI-Crobank ${ }^{\circledR}$ index, is increased by 1 , the operating expenses margin will decrease in average by 2,46\% in 2012 and 2014. Further on, the proportion of interpreted deviations in the total sum of square deviations amounts to $76,11 \%$ in 2012 and $31,84 \%$ in 2013 , and this is considered to be acceptable in the context of this model. The correlation coefficient ( $r=0.87$ in 2012 and $r=0,56$ in 2013) indicated strong to medium level of positive linear connection of the variables in the observed model.

If we observe the influence of corporate governance on variation in the success of business performance measured by the return on equity, with the level of significance of $1 \%$ in 2011, $5 \%$ in 2012 and $10 \%$ in 2014, the null hypothesis $\mathrm{H}_{0}$ is rejected. The

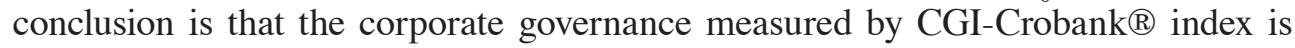
significant for the explanation of variations in the successful performance measured by the return on equity $\left(\mathrm{H}_{2}\right)$. Further on, the semi-log linear model shows that if the quality of corporate governance in the analysed banks increases by 1 within the 
CGI-Crobank ${ }^{\circledR}$ index context, the success of business performance measured by the return on equity will increase in average by 5,52 percent $(6,38 \%$ in $2011,4,10 \%$ in 2012, 6,08 in 2014). Among the observed variables there is a positive linear link of strong to medium intensity ( $r=0.84$ in 2011, $r=0,59$ in 2012 and $r=0,56$ in 2014), and the model itself interprets 70,98\% in 2011, 35,65\% in 2012 and 32,02\% in 2014 of deviations.

Regression analysis determined the correlation between the corporate governance practice and successful bank performance measured by the margin of non-interest income. Taking into account the significance level of $10 \%$, the null hypothesis $\mathrm{H}_{0}$ for years 2013, 2014 and 2015 is dismissed. In other words, it can be concluded that the corporate governance practice measured by CGI-Crobank ${ }^{\circledR}$ index is significant for the explanation of variations in the business performance measured by the margin of non-interest income in 2013, 2014 and $2015\left(\mathrm{H}_{4}\right)$. In this way, the change in the quality of corporate governance by 1 will result in an increase of net interest margin by the average of 1,46 percent (2013), 1,45 percent (2014), respectively 1,67 percent (2015). This also indicates the existence of positive linear link among the observed variables. The determination coefficient of the observed model amounts to 22,55\% (2013), 24,86\% (2014) that is $21,62 \%$ (2015), which is considered acceptable. The correlation coefficient ( $r=0.47$ in 2013, $r=0,49$ in 2014 and $r=0,49$ in 2015) indicated to medium level of positive linear connection of the variables in the observed model.

Furthermore, regression analysis determined the correlation between the corporate governance practice and successful bank performance measured by the Tobin's Q with the level of significance of 1\% in 2014, 10\% in 2011, 2012 and 2015, the null hypothesis $\mathrm{H}_{0}$ is rejected. The conclusion is that the corporate governance measured by CGI-Crobank ${ }^{\circledR}$ index is significant for the explanation of variations in the successful performance measured by the Tobin`s $\mathrm{Q}\left(\mathrm{H}_{6}\right)$. Further on, the semi-log linear model shows that if the quality of corporate governance in the analysed banks increases by 1 within the CGI-Crobank ${ }^{\circledR}$ index context, the success of business performance measured by the Tobin's $\mathrm{Q}$ will increase in average by 1,29 points in 2011, 1,30 in 2012, 5,17 in 2014 and 3,21 in 2015. Among the observed variables there is a positive linear link of medium intensity $(r=0.49$ in $2011, r=0,52$ in $2012, r=0,76$ in 2014 and $\mathrm{r}=0,52$ in 2015), and the model itself interprets $24,01 \%$ in $2011,27,91 \%$ in 2012, 28,79\% in 2014 and 27,13\% in 2015 of deviations.

By observing the relation between the corporate governance practice measured by the CGI-Crobank ${ }^{\circledR}$ index and the successful performance of the observed banks measured by the return on assets $(2011,2012,2015)$, return on equity $(2013,2015)$, interest margin (2011, 2012, 2013, 2014), non-interest income margin (2011, 2012), operation expenses margin (2011, 2014, 2015) and Tobin's Q (2013), no significant correlation was determined among the mentioned indicators and CGI-Crobank ${ }^{\circledR}$ index. However, based on the analysed significance levels, within the context of the previously mentioned models, the null hypothesis cannot be rejected taking into ac- 
count that the empirical significance level is higher that the observed significance level ( $\mathrm{p}$-value $\left.>\alpha \Rightarrow \mathrm{H}_{0}\right)$.

\section{Limitations and Recommendations}

In the course of analysing the corporate governance practice measured by the corporate governance index of the business banks and particular bank profitability indicators, as well as modern company success indicator Tobin's Q for the observed period (2011-2015), a limitation occurred which should be definitely taken into consideration so that the results would not be generalized. The biggest limitation in this research is a relatively small intentional sample, made of 9 banks but still the banks which have available the annual questionnaires of the codex of corporate governance in each analysed year in the period of 5 years. However, the research results can serve as guidelines for further research in this area. The basic recommendation for further research would be to use a bigger sample and extend the time frame taken for the analysis. This should be done having in mind that in the analysed time frame the critical values were outliers which significantly influenced the obtained results. The authors primarily refer to 2013, when most of the observed banks reported losses, and this had a direct influence on the results of regression models. Further on, the entities differ in the sample regarding the size of the bank, which can be a cause of heteroscedascity of the obtained regression models. For any further research it is recommended to divide the banks according to the basic criteria (size of a bank) into 2 samples. This would eliminate the disruption of linear regression premises. Likewise, this research can take into account certain aspects of corporate governance. The dependability of those aspects and certain profitability indicators, i. e. the level of success in Croatian banks, can be tested. The size variable can be measured as the natural logarithm of total assets of each analysed bank. Also according to Pervan, Pelivan and Arneric (2015) we can dived banks into four basic groups, unprofitable banks those who have a negative value of return on asset, low profitable banks whose return on asset takes the up to $1 \%$, moderately profitable banks whose return on asset in in the range between $1 \%$ and $2 \%$ and profitable banks whose return on asset is higher than $2 \%$. Furthermore, it is recommended to use some control variables such as profitability of banks in the previous period, natural logarithm of market capitalization, solvency risk, board size in the turns of natural logarithm of number of members in board, non-executive director's calculated as total non-executive directors by total member in boards, leverage calculated by total debts over total equity and previously mentioned bank size calculated by natural logarithm of total assets. The gained models test the problem of the existence of heteroscedascity, and based on the analysis of the scatter plot it can be concluded that heteroscedascity does not exist. Particularly, the analysed residuals do not show a systematic deviation for different 
values of the independent variables. It should be taken into account that the results are influenced by numerous factors which are not directly influenced by the observed banks, but arise from national legal frameworks and market state (GDP, income per inhabitant, and so on).

\section{Conclusion}

The research problem consisted of testing the hypotheses of whether the corporate governance practice measured by the CGI-Crobank ${ }^{\circledR}$ index was significant for the explanation of the variations in the success, that is profitability of commercial banks in the Republic of Croatia measured by the return on assets, return on equity, interest margin, margin of non-interest income, operating expenses margin and by Tobin's Q for the observed period from 2011 to 2015 . Based on the gained results it can be concluded that corporate governance, measured for the purpose of this article by the developed Corporate Governance Index in Croatian banks (CGI-Crobank ${ }^{\circledR}$ index) has positive and important impact on the successful performance of Croatian banks. Conclusion does not implicate general significance of the corporate governance practice measured by the CGI-Crobank ${ }^{\circledR}$ index for the explanation of the business performance of the Croatian banks considering that the results of the analysis do not confirm all of identified hypotheses for each analysed year. In other words, it can be concluded that a well implemented practice of corporate governance influences the variations in the level of success of banks measured by the return on assets (2013, 2014), return on equity $(2011,2012,2014)$ and net interest margin (2015), margin of non-interest income $(2013,2014,2015)$, operating expenses margin $(2011,2012)$ and Tobin`s Q $(2011,2012,2014,2015)$. The obtained results are considered to be relevant, having in mind that the mentioned indicators are considered to be one of the more significant indicators of the successful bank performance. One of the biggest limitation of this research is relatively small intentional sample which depend of the available annual questionnaires of the codex of corporate governance. Based on the defined limitations, the recommendations for further research imply the introduction of compulsory practice of filling out the annual questionnaires of the corporate governance codex, auditing of the questionnaires from the point of view of formulating and grouping questions. All this should be done with the view of advancing the research by using the created CGI- Crobank ${ }^{\circledR}$ index. The basic recommendation would be to use a bigger sample in further research, as well as to include certain aspects of corporate governance and test their influence on certain profitability indicators in the banks. The research can be advanced by including additional variables with significant influence on bank performance, such as the ones from the external environment (economic, social, political and legal, ethical and other aspects). It would be inter- 
esting, from the aspect of scientific contribution, to make a comparison with other developing countries as well as to include the control variables.

\section{REFERENCES}

Adegbemi, B.O., Donald, I. \& Ismail O. (2012). Corporate governance and bank performance: A pooled study of selected banks in Nigeria. European Scientific Journal. 8(28), 155-164. Retrieved September 14, 2016, from ESI database on the World Wide Web: http://eujournal.org/index.php/esj/ article/view/644. ISSN: 1857 - 7881 (Print)

Al-Sahafi, A., Rodrigs, M. \& Barnes, L. (2015). Does corporate governance affect financial performance in the banking sector?. International Journal of Economics, Commerce and Management. 3(3), 1-26. Retrieved September 14, 2016, from IJECM database on the World Wide Web: http:// ijecm.co.uk/volume-iii-issue-3/. ISSN 23480386.

Bahovec, V. \& Erjavec, N. (2009). Uvod u ekonometrijsku analizu. Zagreb: ELEMENT

Bubbico, R., Giorgino, M. \& Monda, B. (2012). The impact of Corporate Governance on the market value of financial institutions: empirical evidences from Italy. Banks and Bank Systems. 7(2), 1118. Retrieved September 14, 2016, from SSRN: http://papers.ssrn.com/sol3/papers.cfm?abstract_ id=2119497.

Basel Committee on Banking Supervision (2015). Corporate governance principles for banks. Retrieved September 14, 2016, form http://www.bis.org/bcbs/publ/d328.htm.

Imran, A., Muhammad, I., Muhammad, A. \& Naeem, U. (2014). Theory and Empirical Evidence on Corporate Governance from Banking Sector of Pakistan. Business and Economic Research. 4(1), 163-174. DOI: 10.5296/ber.v4i1.5180.

Klapper, L. F. \& Love, I. (2002). Corporate Governance. Investor Protection and Performance in Emerging Markets. World Bank Policy Research Working Paper. 2818, 1-39.

Korent, D., Djundjek, I. \& Klacmer Calopa, M. (2014). Corporate governance practices and firm performance measured by Croatian Corporate Governance Indeks (CCGI®). Economic Research Ekonomska istrazivanja. 27(1), 221-231. Retrieved September 14, 2016, from Taylor \& Francis Online database on the World Wide Web: http://www.tandfonline.com/doi/full/10.1080/133167 7X.2014.952109. DOI: 10.1080/1331677X.2014.952109.

Kraft, E. \& Tirtiroglu, D. (1998). Bank Efficiency in Croatia: A Stochastic-Frontier Analysis. Journal of Comparative Economics. 26(2), 282-300. Retrieved September 14, 2016, for ScienceDirect database on the World Wide Web: http://www.sciencedirect.com/science/article/pii/ S0147596798915177. DOI: 10.1006/jcec.1998.1517.

Love, I. \& Rachinsky, A. (2015). Corporate Governance and Bank Performance in Emerging Markets: Evidence from Russia and Ukraine. Emerging Markets Finance and Trade. 51, 101-121. Retrieved September 14, 2016, from Taylor \& Francis Online database on the World Wide Web: http://www. tandfonline.com/doi/abs/10.1080/1540496X.2014.998945. DOI: 10.1080/1540496X.2014.998945.

Maddala, G.S. (2001). Introduction to Econometrics (3th ed.). England: John Whiley \& Sons Ltd.

Mohammad, Z., Rabiul, I. \& Hasnan A. (2013). Corporate Governance and Bank Performance: The Case of Bangladesh. Retrieved September 14, 2016, from SSRN: http://ssrn.com/abstract=2208903.

Pavkovic, A. (2004). Instrumenti vrednovanja uspjesnosti poslovnih banaka. Zbornik Ekonomskog fakulteta u Zagrebu. 2(1), 179-192. Retrieved September 14, 2016, from Hrcak.srce database on the World Wide Web: http://hrcak.srce.hr/26203?lang=en.

Pejic Bach, M., Posedel, P. \& Stojanovic, A. (2009). Determinante profitabilnosti banaka u Hrvatskoj. Zbornik Ekonomskog fakulteta u Zagrebu. 7(1), 81-92. Retrieved September 14, 2016, from Hrcak. srce database on the World Wide Web: http://hrcak.srce.hr/40546. 
Pervan, M., Pelivan, I. \& Arneric, J. (2015). Profit persistence and determinants of bank profitability in Croatia. Economic Research-Ekonomska Istrazivanja. 28(1), 284-298. Retrieved September 14, 2016, from Taylor \& Francis Online database on the World Wide Web: http://www.tandfonline. com/doi/full/10.1080/1331677X.2015.1041778. DOI: 10.1080/1331677X.2015.1041778.

Tomicic, I., Coric, A. \& Klacmer Calopa, M. (2012). Croatian Banking Sector Research: Relationship between Ownership Structure, Concentration, Owners' Type and Bank Performance. Journal of Information and Organizational Sciences (JIOS). 36(2), 159-167. Retrieved September 14, 2016, from Hrcak.srce database on the World Wide Web: http://hrcak.srce.hr/93740.

Vuckovic, M. (2007). Analiza ucinkovitosti hrvatskih banaka pomocu visekriterijskog programiranja. Ekonomski fakultet Zagreb. 7, 1-16. Retrieved September 14, 2016, from Hrcak.srce database on the World Wide Web: http://hrcak.srce.hr/136964.

Zager, K., Mamic Sacer, I., Sever, S. \& Zager, L. (2009). Analiza financijskih izvjestaja. Zagreb: MASMEDIA d.o.o. 